\title{
The Strategy of Bad Loans "Pang Pade Payu" in Village Credit Institution in Buleleng District
}

\section{Ni Made Sri Ayuni ${ }^{1 *}$, Ni Wayan Novi Budiasni ${ }^{2}$}

1,2 Sekolah Tinggi Ilmu Ekonomi Satya Dharma Singaraja

\section{A R T I C L E I N F 0}

\section{Article history:}

Received 19 August 2019 Received in revised form 16 September 2019 Accepted 15 October 2019 Available online 26 November 2019

\section{Keywords:}

Internal Control System, Credit Policy and Bad Loans Settlement Strategy, Bad Loans Strategy

\begin{abstract}
A B S T R A C T
This research was motivated by a phenomenon in the district of Buleleng related to the number of LPD with conditions that are less healthy to jammed has increased. In addition, the number of LPD that are stuck in Buleleng regency is the highest in Bali. The purpose of this study is to determine the implications of the internal control system and credit policy on the credit settlement strategy, the settlement of bad loans is settled by the principle of "Pang Pada Payu". The number of samples in this study were 60 LPD selected based on the stratified random sampling method. The data analysis technique used in this study was a structural equation model (seminal structural modeling) based on variance or component based sem with smartpls 3.0 analysis tools. Based on the results of testing the internal control system has a significant positive effect on the strategy of settlement bad loans "Pang Pade Payu" Bad Loans Strategy in LPD in Buleleng Regency. Both credit policies have a significant positive effect on the strategy of settlement bad loans "Pang Pade Payu" Bad Loans Strategy in Village Credit Institutions in Buleleng Regency.
\end{abstract}

\footnotetext{
* Corresponding author.

E-mail addresses: nimadesriayuni90@gmail.com (Ni Made Sri Ayuni)
} 


\section{Introduction}

LPD (Village Credit Institutions) has a management system that is thick with customary law and local wisdom in Bali. LPD has a unique character, referring to Perda and awig-awig (customary rules of society) (Sudiartha, 2017). Along with its development, there were LPD problems with unhealthy conditions and even LPD were jammed which hampered the survival of LPD in Bali. Bad loans arises because the manager is not selective before deciding the realization of credit to borrowing customers (Saputra, 2015). The same thing was conveyed by Sudiartha (2017), who stated that, LPD that was stuck and LPD that were unhealthy occurred due to inadequate implementation of management systems, and inadvertent lending. In Buleleng there is the highest number of Jammed LPD in Bali, which is 25 LPD (balitribun.co.id, 2017). In addition, since the period of 2016 to 2018 in the first quarter, the number of LPD in Buleleng Regency which was in an unhealthy condition to a standstill increased to 65 LPD units.

According to $\mathrm{Bu}$ (2006) in Dewi and Yasa (2012), the internal control system must be implemented as well as possible in granting credit. In addition, Mulyadi (2001) also stated that often the credit officers were less selective in selecting customers who applied for credit so that credit was easily disbursed. There are important aspects that need to be considered related to the internal control system in granting credit, including the control environment, accounting system and control procedures that are implemented and adjusted to the credit policies owned by each LPD. There are results of previous studies by Isabella, et al (2013), who found that the internal control system had a significant effect on bad loans at one of the financial institutions in the city of Palembang. These results reinforce the reason for the LPD to pay attention to internal control systems in lending.

The results of a previous study by Putri (2015) in the LPD of Lebu Village, Sidemen, Karangasem Regency found that to avoid bad loans the LPD must have a good credit policy. In addition, Mudrajad Kuncoro and Suhardjono (2002), stated that weak credit management or policies affect credit risk in an LPD such as bad loans. The way to overcome this problem LPD must have a good credit risk management strategy. According to Nuryani, et al (2017), in Bali there is a principle of "Pang Pada Payu" which is applied by business people in solving the problem of imbalance between business, society and the environment.

This principle has been applied by the Kedonganan LPD as a strategy to resolve bad loans, with the hope of obtaining the same benefits between the customer and the LPD. The principle of "Pang Pada Payu" is also recommended to be applied by Pradnyani (2017) in resolving bad loans, because "Pang Pada Payu" (mutual benefit and mutual empowerment), which makes us wiser and fairer, and evenly distributed for the welfare of rural communities. So that the main objective of establishing an LPD in Bali whose management is based on local wisdom and the welfare of rural communities can be realized. Based on these problems, the researcher is interested in conducting research on the implications of the internal control system and credit policy on the settlement of bad loans where the "Pang Pada Payu" strategy is used as a tool to resolve the bad loans that occur in LPD of the Regency of Buleleng. So the problems to be examined are: (1). Does the internal control system influence the bad loans settlement strategy? (2). Does the credit policy affect the bad loans settlement strategy?

According to Boynton (2006) Internal control is a process carried out by the board of directors, management, and other personnel in an entity, which is designed to provide adequate confidence regarding the achievement of objectives in the following categories: 1) The reliability of financial reporting, 2) Compliance with applicable laws and regulations, 3) Effectiveness and efficiency of operations

Systems according to James (2007) systems are groups of two or more interconnected components or subsystems that function with the same goal. Furthermore Warens (2008) argues that the internal control system consists of policies and procedures designed to provide reasonable assurance to management that the organization has achieved its goals and objectives. These policies and procedures are often called controls and collectively shape the control of the entity.

Mulyadi (2001) states that often credit officers are less selective in selecting customers who apply for credit to the LPD so that credit is easily disbursed. This indicates that the credit procedures that should have been carried out properly and correctly were even carried out in moderation. Thus, a good internal control system is needed by the LPD to reduce the occurrence of bad loans. There are important aspects that need to be considered related to the internal control system in granting credit, including the control environment, accounting system and control procedures for each LPD.

According to Rivai (2005), the provisions of credit policy need to be determined so that each financial institution has and applies a good credit policy and is able to oversee the overall credit portfolio and set standards in the lending process individually and have standards / measures that contain internal supervision at all stages of the process credit. According to Hasibuan (2006) credit policies 
include:

1) Bankable, meaning that the credit to be financed should meet the criteria of safety, which is a certainty in the repayment of credit according to the credit schedule and time period and Effectiveness, meaning that the credit granted is actually used for financing, as stated in the credit proposal.

2) Investment policy is investment of funds which is always associated with the source of the relevant funds. These investment funds are channeled in the form of, among others:

a) Primary Investment, namely investment made to purchase bank facilities and infrastructure such as the purchase of offices, machinery and stationery. These funds must come from their own funds because they are unproductive and long term.

b) Secondary Investment, i.e. infestation carried out by extending credit to the public. This investment is productive. The period of credit distribution must be adjusted to the length of savings so that bank liquidity is guaranteed.

c) Risk policy, which means that in channeling credit, it must carefully take into account indicators that may cause credit default risk and determine ways of resolution.

d) Credit distribution policy, which means that credit must be distributed to a variety of economic sectors, and with a large number of borrowers.

e) The interest rate policy, which means giving credit must take into account the monetary situation, economic conditions, interbank competition, and inflation rates to set credit interest rates.

According to Hermanto (2006), bad loans are non-current loans and have reached maturity and cannot be settled by the customer concerned. Settlement of bad loans according to Hasibuan (2006) can be done in the following manner:

1) Reschedulling

Reschedulling is a change in credit terms that only involves payment schedules or time periods including grace periods and changes in the amount of credit installments. Debtors provided a rescheduling facility are customers who show good faith and honest character and are willing to pay, and according to the bank, their business does not require additional funds or liquidity.

2) Reconditioning

Reconditioning is a change in part or all of the credit terms including changes in the payment schedule, time period, interest rates, delay in part or all interest, and other terms. Changes to credit terms do not include adding funds and converting some or all of the credit to company equity.

3) Restructuring

Restructuring is a change in credit terms relating to: Addition of bank funds, conversion of part / all of the arrears of interest into new loan principal and conversion of part / all of the credit to bank participation or take other partners to add to the participation.

4) Liquidation

Liquidation is the sale of goods used as collateral in order to pay off debts. The liquidation is carried out on the category of credit that according to the bank really cannot be helped to be restored, or the customer's business has no prospect to be developed. Win-win Solutian is a situation where both parties to a dispute (conflict) both benefit in a transaction or agreement and neither party feels defeated. According to Simatupang (2007), with a 'win-win solution', many things can be achieved. There are at least two types of success that can be achieved namely:

a. Communication strategies become easier because the aim is not to defeat but to help their partner.

b. Getting a win-win solution in a communication strategy is unlimited profit because the project will be more perfect and future projects will be open.

Furthermore Sumarto (2012) states that a win-win solution can strive to facilitate the accommodation of various interests in disputes so as not to become victims of conflicts that consume and damage both parties.

Pang Pada Payu is an expression in the middle Balinese Language (Balinese variant middle or middle language) whose free translation is 'so that you can' or 'so that you are together'. What is meant by 'can' or 'can be' is nothing but achieving the goals of each party. Although the goals achieved were not 
entirely on target. According to Budiarna (2007), in his dissertation examines the application of the principle of pang pada payu in Indonesian Economic law. According to him, the principle of pang pada payu is the convention of peaceful settlement of disputes between individuals and groups which means 'to be equally benefited'. The principle of pang pada payu, Pang Pada Payu's principle in Indonesian Economic Law is a kind of traditional arbitration of Hindu community in Bali.

The principle of pang pada payu is now widely used by business people in an effort to resolve imbalances between business, society and the environment. Not only used by community groups in Bali, some companies believe in the principle of pang pada payu used to run each program to work with the aim of getting the same benefits from both parties. Business entities entrust the use of the principle of pang pada payu in solving problems such as the Kedonganan LPD. Kedonganan LPD uses the principle of pang pada payu to solve the problem of bad loans. This is usually applied when there are customers who are unable to repay loans, Kedonganan LPDs do not necessarily immediately seize assets used as collateral, but will look for other alternative solutions to resolve this problem without harming (source: Kedonganan LPD web, in the Principles article of Pang Pada Payu in LPD governance).

According to Novitayanti and Baskara (2012) this applied policy has made a good contribution to banking activities so that the value of Non Performing Loan (NPL) generated by PT Bank Sinar Harapan Bali has shown a figure below 5\% in the 2007-2011 period. In addition, based on the results of interviews with the occurrence of problem loans at PT Bank Sinar Harapan Bali caused by the debtors. Furthermore Dewi and Yasa (2012) internal control system in an effort to reduce the occurrence of bad loans, $19.44 \%$ of the LPD has a level of effectiveness that is less effective, $16.67 \%$ have an adequate level of effectiveness and the rest with the largest percentage of $63.89 \%$ from the LPD is included in the category of very effective.

\section{Method}

In this study examines the causal relationship between the internal control system, credit policy and the bad loans settlement strategy through the concept of Pang Pada Payu. The development of models in this study seeks to predict causality between variables. The location of this research is the Village Credit Institution (LPD), with the selection of regional coverage as LPD throughout the Buleleng Regency. Buleleng Regency consists of nine districts namely, Banjar, Sukasada, Sawan, Kubut added, Tejakula, Seririt, Busungbiu, Gerogak, and Buleleng districts. The sample in this study was 60 LPD calculated by the Slovin formula with the Stratified Random Sampling method.

The research instrument used was a questionnaire as a data collection tool. Of the 60 questionnaires distributed, all questionnaires were returned but 1 was not filled out completely only 59 questionnaires could be processed. The data that has been collected is analyzed by (Structural Equation Modeling-SEM) based on variance or Component based SEM, which is famously called Partial Least Square (PLS) Visual version 1.0.04bl.

\section{Result and Discussion}

In this study, there are three constructs consisting of two exogenous variables, namely the first Internal Control System which is measured by three indicators, namely ICS1, ICS2, and ICS3. Second, the Credit Policy as measured by two indicators CP1 and CP2. The endogenous variable in this study is the Bad Loans Settlement Strategy measured by four indicators namely BLSS1, BLSS2, BLSS3 and BLSS4.

\section{A. Rating The Outer Model or Measurement Model}

The construct is said to have high reliability if the Composite Reliability value is above 0.70 , the Cronbachs Alpha value is above 0.60, rho_A is above 0.70, and AVE is above 0.50 (Ghozali, 2008). Table 3.1 presents Cronbachs Alpha, rho_A, Composite Reliability and Average Variance Extracted (Ave) values for all variables. 
Table 1. The Score of Cronbachs Alpha, rho_A, Composite Reliability And Average Variance Extracted (Ave)

\begin{tabular}{lcccc}
\hline & Cronbach's Alpha & rho_A & $\begin{array}{c}\text { Composite } \\
\text { Reliability }\end{array}$ & $\begin{array}{c}\text { Average } \\
\text { Variance } \\
\text { Extracted (AVE) }\end{array}$ \\
\hline Credit Policy & 0.768 & 0.782 & 0.895 & 0.810 \\
Internal Control System & 0.863 & 0.863 & 0.916 & 0.785 \\
Bad Loans Settlement Strategy & 0.830 & 0.847 & 0.887 & 0.662 \\
\hline
\end{tabular}

Table 1. shows that all constructs in this study produced the score of Composite Reliability is above 0.70 and the score of Cronbachs Alpha is above 0.60 . The lowest score of Composite Reliability is in the construction of bad credit settlement strategies with a value of 0.895 and Cronbachs Alpha is in the credit policy construct with a score of 0.768 . It can be concluded that the construct in this study is reliable. Furthermore AVE score is above 0.5 for all constructs contained in the research model. The lowest score of AVE is 0.662 in the Bad Loans Settlement Strategy construct, so it can be concluded that the construct in this study is valid. Rho_A values above 0.70 for all constructs.

\section{B. Structural Model Testing (Inner Model)}

In assessing the model with PLS, it starts by looking at the R-square for each latent dependent variable (Ghozali, 2009). Table 3.2 is the result of R-square estimation using SmartPLS.

Table 2. The Score of $R-S Q U A R E$

\begin{tabular}{lcc}
\hline & R Square & R Square Adjusted \\
\hline Bad Loans Settlement Strategy & 0.761 & 0.753 \\
\hline & & Source: Data processed
\end{tabular}

Based on the above determination coefficient data it is known that the score of R-Square of the Bad Loans Settlement Strategy of 0.761 the magnitude of the R-Square number of 0.761 equals $7.61 \%$ can be explained by the construct variable of the Internal Control System and Credit Policy.

\section{Hypothesis Testing}

The basis used in testing hypotheses is the score contained in the output result for inner weight.

Table 3. provides estimated outputs for testing structural models.

Table 3. Result for Inner Weight

\begin{tabular}{lccccc}
\hline & $\begin{array}{c}\text { Original } \\
\text { Sample (0) }\end{array}$ & $\begin{array}{c}\text { Sample } \\
\text { Mean } \\
\text { (M) }\end{array}$ & $\begin{array}{c}\text { Standard } \\
\text { Deviation } \\
\text { (STDEV) }\end{array}$ & $\begin{array}{c}\text { T Statistics } \\
\text { (|O/STDE) }\end{array}$ & $\begin{array}{c}\text { P } \\
\text { Val } \\
\text { ues }\end{array}$ \\
\hline $\begin{array}{l}\text { Credit Policy -> Bad Loans } \\
\text { Settlement Strategy }\end{array}$ & 0.683 & 0.687 & 0.078 & 8.788 & 0.00 \\
\hline $\begin{array}{l}\text { Internal Control System -> Bad } \\
\text { Loans Settlement Strategy }\end{array}$ & 0.246 & 0.245 & 0.086 & 2.872 & 0.00 \\
\hline
\end{tabular}

Source: Data processed

\section{Internal Control System toward Bad Loans Settlement Strategy}

The results of testing the first hypothesis indicate that the relationship between the Internal Control System variable and the Bad Loans Settlement Strategy shows a parameter coefficient of 0.246 with a $t$ value of 2.872 . This value is greater than $t$ Table $(1,960)$. These results indicate that the Internal Control System of the Bad Loans Settlement Strategy has a positive and significant relationship. The $1^{\text {st }}$ hypothesis is accepted. The internal control system influences the bad credit settlement strategy. To anticipate the occurrence of bad loans in the LPD, the officer in the credit department must understand the lending standards, and be more selective in selecting customers who apply for credit in the LPD. Thus, a good internal control system is needed by the LPD to reduce the occurrence of bad loans. There are important aspects that need to be considered related to the internal control system in granting credit, including the control environment, accounting system and control procedures for each LPD. 


\section{E. Credit Policy toward Jammed Credit Settlement Strategy}

The results of the second hypothesis testing show that the relationship between the variable of Credit Policy with the Bad Loans Settlement Strategy shows a parameter coefficient of 0.683 with a t value of 8.788. This value is greater than $t$ Table $(1,960)$. This result means that credit policy has a positive and significant relationship to the settlement of bad loans. Hypothesis 2 is accepted. The credit policy influences the bad loans settlement strategy.

The LPD in Buleleng Regency must have and implement a good credit policy in order to be able to oversee the overall credit portfolio and set standards in the lending process individually and have standards / measures containing internal supervision at all stages of the credit process. To maintain the existence of the LPD principle "Pang Pada Payu" to resolve the problem of bad loans. This is usually applied when there are customers who are unable to pay for loans rescheduling, re-requirements, rearrangement and liquidation.

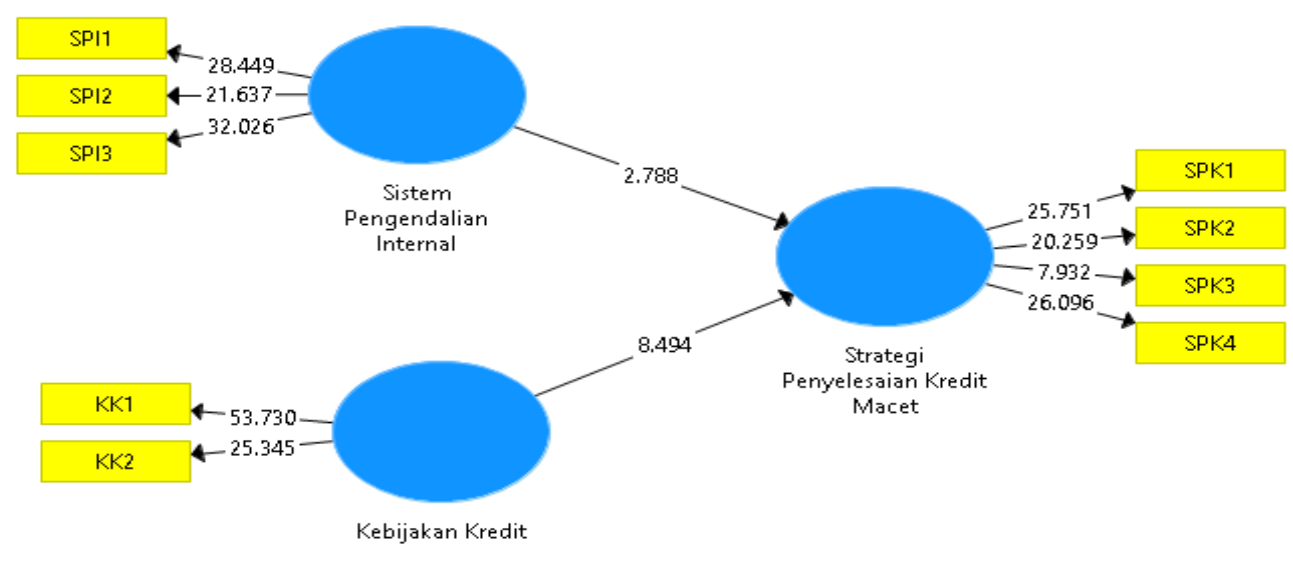

Picture 1. Bootstraping Score

Source : Data Processed

\section{Conclusion}

The conclusion in this study is that the internal control system has a significant positive effect on the strategy of settling bad loans "Pang Pade Payu" Bad Loans Strategy at village credit institutions in Buleleng Regency. Both credit policies have a significant positive effect on the strategy of settling bad loans "Pang Pade Payu" Bad Loans Strategy in village credit institutions in Buleleng Regency.

\section{References}

Balitribun.co.id.2017. 150 LPD Di Bali Dinyatakan Bangkrut. Tanggal akses : 2 Agustus 2018.Tersedia:http://balitribune.co.id/content/150-lpd-di-bali-dinyatakan-bangkrut

Budiarna, I Nyoman, 2007, Penyelesaian Sengketa Kredit Macet Dihubungkan Dengan Arbitrase Sebagai Upaya Pengembangan Hukum Ekonomi Indonesia. Universitas Padjadjaran, Bandung

Dewi, Ni Made Irma Indra, dan Yasa,Gerianta Wirawan.2012. Analisis Efektivitas Struktur Pengendalian Intern dalam Menekan Kredit Macet Pada Lpd Se-Kabupaten Buleleng. Fakultas Ekonomi Universitas Udayana.

Ghozali, Imam (2008) . Structural Equation Modeling Metode Alternatif dengan Partial Least Square Edisi Kedua. Yogyakarta : Badan Penerbit Universitas Diponegoro.

Hasibuan, Malayu S.P, 2006, Manajemen Dasar, Pengertian, dan Masalah,Edisi Revisi, Bumi Aksara:Jakarta. 
Hermanto. 2006. Faktor-Faktor Kredit Macet pada PD.BPR BKK Ungaran Kabupaten Semarang. Skripsi Fakultas Ekonomi Universitas Negeri Semarang

Isabella, dkk. 2013. Pengaruh Pengendalian Internal Terhadap Kredit Macet (Studi Kasus Pada Finance di Kota Palembang). Jurusan Akuntansi STIE Multi Data Palembang.

James, A. Hall, 2007. Sistem Informasi Akuntansi. Edisi Ketiga, Terjemahan Amir Abadi Yusuf, Salemba Empat, Jakarta.

Mudrajad Kuncoro dan Suhardjono.2002. Manajemen Perbankan. Yogyakarta: BPFE

Mulyadi. 2001. Sistem Akuntansi Edisi Tiga. Jakarta : Salemba Empat.

Mulyadi. 2001. Sistem Akuntansi Edisi Tiga. Jakarta : Salemba Empat.

Novitayanti, Ni Luh Angga, dan Baskara, I Gde Kajeng. 2012. Analisis Kebijakan Perkreditan Dan Pengaruh Ldr Terhadap Npl Pada Bank Sinar. Fakultas Ekonomi Universitas Udayana

Nuryani, Ni Nyoman Juli, dkk.2017.Pang Pada Payu for Long Lifetime Bussines. The $1^{\text {st }}$ International Conference on Family Bussines and Entrepreneurship. STIE Satya Dharma Singaraja

Pradnyani, Ni Putu Wira Ayu, dkk. 2017. Konsep "Pang Pada Payu" Dalam Penyelesaian Kredit Macet Di Badan Usaha Milik Desa (Studi Kasus Di BUM Desa Banjarasem Mandara, Desa Banjarasem, Kecamatan Seririt, Kabupaten Buleleng). E_journal S1 Ak Universitas Pendidikan Ganesha Jurusan Akuntansi Program S1 (Volume 7 No 1 Tahun) 2017

Putri,Dwi Narita. 2015. Manajemen Risiko Kredit Pada Lembaga Perkreditan Desa (Lpd) Desa Lebu Sidemen Karangasem Tahun 2015. Jurnal Jurusan Pendidikan Ekonomi (JJPE) Volume: 5 Nomor: 1 Tahun: 2015. Universitas Pendidikan Ganesha.

Rivai, Basri. (2005). Performance Appraisal. Cetakan Pertama, PT Raja Grafindo Persada, Jakarta

Saputra, Komang Adi Kurniawan. 2015. Prinsip Pang Pada Payu Sebagai Dimensi Good Governance dalam Sengketa Kredit Macet (Studi Fenomenologi pada LPD Desa Kerobokan, Kabupaten Buleleng-Bali). Universitas Pendidikan Ganesha

Sudiartha, Anak Agung Ngurah Gede.2017. Lembaga perkreditan desa sebagai penopang ke-ajegan budaya ekonomi masyarakat Bali. Jurnal Kajian Bali Volume 07, Nomor 02, Oktober 2017. Universitas Hindu Indonesia

Warren, Carl.S., Reeve, James.M.,Fes Philip. (terjemahan Aria Farahmita). 2008. Pengantar Akuntansi. Jakarta: Salemba Empat 